\title{
BIOSURFACTANTS PRODUCED BY METAL-RESISTANT Pseudomonas aeruginosa ISOLATED FROM Zea mays RHIZOSPHERE AND COMPOST
}

\author{
BIOSURFACTANTES PRODUCIDOS POR LA Pseudomonas \\ aeruginosa AISLADA DE LA RIZÓSFERA \\ Y COMPOSTA DE LA Zea mays
}

\section{${ }^{1}$ Aguirre-Noyola J. L, ${ }^{2}$ Romero Ramírez Y, ${ }^{3}$ Ruvalcaba Ledezma J. C, ${ }^{4}$ Forero Forero $A$. $V$, ${ }^{5}$ León Rodríguez $R$, and ${ }^{* 6}$ Toribio Jiménez $J$}

\author{
${ }^{1}$ Maestro en Biociencias, Facultad de Ciencias Químico Biológicas. \\ Universidad Autónoma de Guerrero, Chilpancingo, Guerrero. México. \\ 2,6Profesora-Investigadora de Tiempo Completo, Facultad de Ciencias Químico Biológicas, UAGro. México. \\ ${ }^{3}$ Profesor-Investigador de Tiempo Completo, Instituto de Ciencias de la Salud -UAEH, México. \\ ${ }^{4}$ Doctora en Ciencias, Profesora de Asignatura, Facultad de Ciencias, UNAM. México. \\ ${ }^{5}$ Doctor en Ciencias, Instituto de Investigaciones Biomédicas, UNAM, México. \\ ${ }^{1}$ jaguirre@ibt.unam.mx , ${ }^{2}$ yromero@uagro.mx , ${ }^{3}$ jesus_ruvalcaba@uuaeh.edu.mx, \\ ${ }^{4}$ avforerof@ciencias.unam.mx , ${ }^{5}$ renato@biomedicas.unam.mx, \\ *Corresponding author. J Toribio Jiménez. Email: ${ }^{6} 15157$ @uagro.mx
}

\begin{abstract}
Contextualization: Pseudomonas aeruginosa is capable of producing biosurfactants which have many uses in bioremediation and the production of antiviral, antibacterial, antiparasitic, sporicidal and antifungal agents, among others.
\end{abstract}

Knowledge gap: This study describes the production of mono and di-rhamnolipid biosurfactants by $P$. aeruginosa strains isolated from Zea mays rhizosphere and composts in the state of Guerrero, Mexico.
Purpose: The overall aims were to investigate biosurfactant, pyocyanin production, and tolerance to heavy metals and antimicrobial activity capacity than biosurfactants produced from $P$. aeruginosa strains from corn rhizosphere and compost in Mexico.

Methodology: Biosurfactant production was determined based hemolysis on blood agar, blue halos in CTAB-Methylene blue agar, drop collapse test and production of foam on PPGAS 
broth, the emulsion index (IE24) and antibacterial capacity. The strains were identified by sequence of the 165 rDNA gene and their resistance to heavy metals were also evaluated.

Results and conclusions: Two strains isolated from Zea mays rhizosphere (PAM8, PAM9) were the best biosurfactant producers and their extracts showed antimicrobial activity against Grampositive and Gramnegative bacteria. PAM8 and PAM9 showed $>30 \%$ of cellular hydrophobicity to hydrocarbons, and were capable of emulsifying toluene, cyclohexane, petroleum, diesel and oils. All strains showed the same profile of heavy metal tolerance (As5+ $>$ As3 $+>\mathrm{Zn} 2+$ $>\mathrm{Pb} 2+>\mathrm{Fe} 3+>\mathrm{Cd} 2+>\mathrm{Cu} 2+>\mathrm{Cr} 6+$ in concentrations of $20,10,10,6,4,4,2$ and 2 mM., respectively). The isolation of biosurfactant-producing and heavy-metal tolerant bacteria from Zea mays rhizosphere and compost in Guerrero demonstrates the capacity for this region to harbor potentially important microbial strains for industrial or bioremediation applications.

Keywords: Rhamnolipids, hydrocarbons, bioremediation, biotechnological applications.

\section{RESUMEN}

Contextualización: la Pseudomonas aeruginosa es capaz de producir biosurfactantes que tienen muchos usos en la biorremediación y producción de agentes antivirales, antibacterianos, antiparasitarios, esporicidas y antifúngicos, entre otros.

Vacío de conocimiento: este estudio describe la producción de biosurfactantes mono y di-ramnolípidos por cepas de $P$. aeruginosa aisladas de la rizosfera y compostas de Zea mays en el estado de Guerrero, México.
Propósito del estudio: los objetivos generales fueron investigar la producción de biosurfactantes, piocianina y tolerancia a metales pesados y la capacidad de actividad antimicrobiana de los biosurfactantes producidos por cepas de $P$. aeruginosa aisladas de rizosfera y composta en México.

Metodología: Se determinó la producción de biosurfactantes con base en la hemolisis agar sangre, halos azules en agar CTAB-azul de metileno, ensayo de colapso de gotas, producción de espuma en medio PPGAS, índice de emulsión (IE24) y capacidad antibacterial, las cepas se identificaron por la secuencia del gen del 165 y también se evaluó la resistencia a metales pesados.

Resultados y conclusiones: Dos cepas aisladas de la rizosfera de Zea mays (PAM8, PAM9) fueron las mejores productoras de biosurfactantes, y sus extractos mostraron actividad antimicrobiana frente a bacterias Grampositivas y Gramnegativas. PAM8 y PAM9 mostraron $>30 \%$ de hidrofobicidad a hidrocarburos y fueron capaces de emulsionar tolueno, ciclohexano, petróleo, diésel y aceites. Todas las cepas mostraron el mismo perfil de tolerancia a metales pesados $\mathrm{As}^{5+}>\mathrm{As}^{3+}>\mathrm{Zn}^{2+}>\mathrm{Pb}^{2+}>\mathrm{Fe}^{3+}>\mathrm{Cd}^{2+}>$ $\mathrm{Cu}^{2+}>\mathrm{Cr}^{6+}$ en concentraciones de 20, 10, 10 , 6, 4, 4, 2 y 2 mM., respectivamente). El aislamiento de bacterias productoras de biosurfactantes y tolerantes a metales pesados de la rizosfera y composta de Zea mays en Guerrero demuestra que la región alberga cepas microbianas potencialmente importantes para aplicaciones industriales o de biorremediación.

Palabras clave: Ramnolípidos, hidrocarburos, biorremediación, aplicaciones biotecnológicas. 


\section{GRAPHIC ABSTRACT}

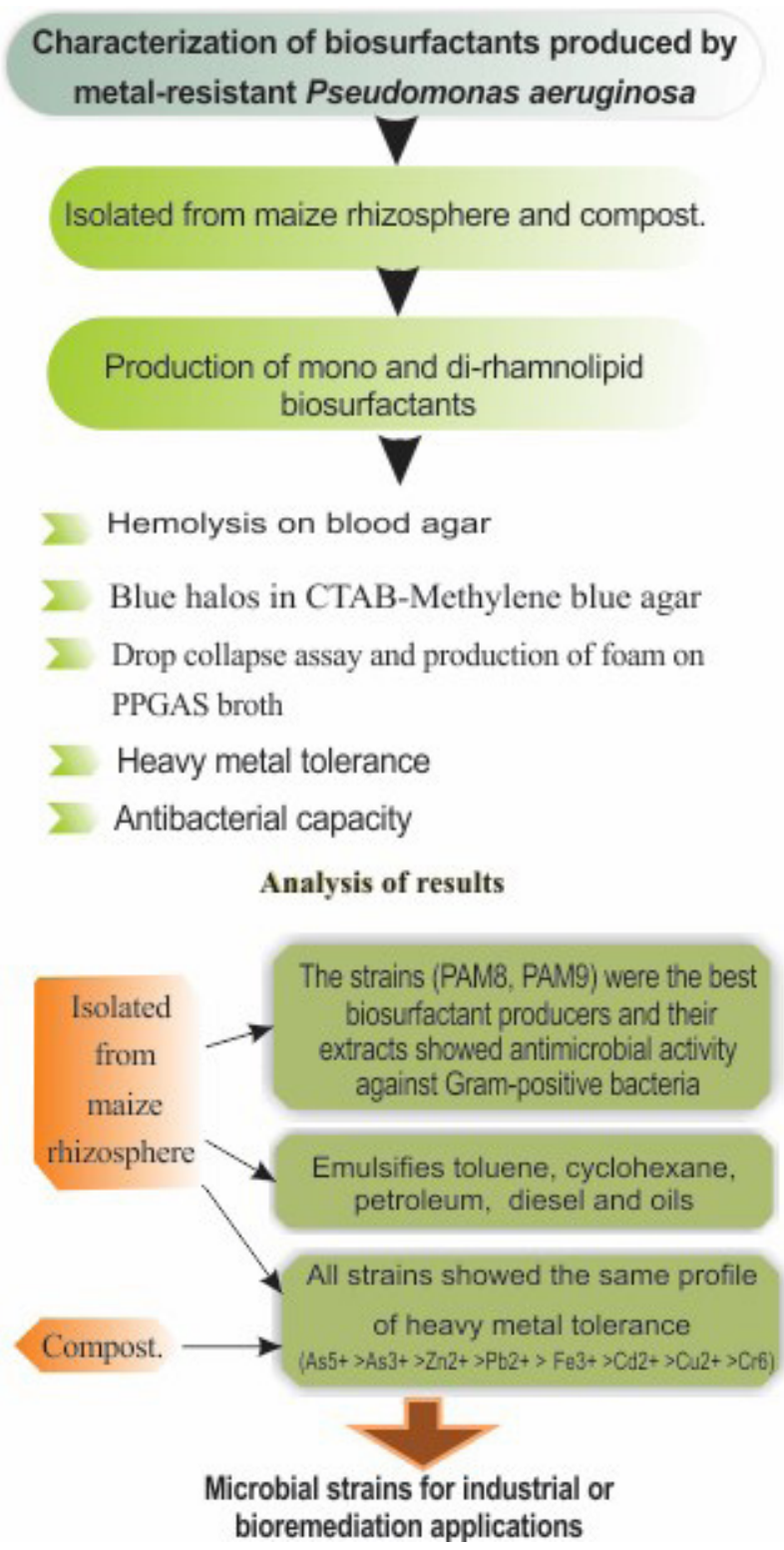

\section{INTRODUCTION}

Biosurfactants are molecules that lower the surface tension and increase the solubility between solutions that are non-miscible (Toribio Jimenez et al., 2014). Among their many applications, they may act as emulsifying, foaming agents and wetting agents (PacwaPłociniczak et al., 2011; Satpute et al., 2010)2011; Satpute et al., 2010. Biosurfactants are produced by microorganisms such as bacteria, yeast and filamentous fungi, and are often considered to be environmentally friendly compounds. They have been mostly studied in the context of microbial enhanced oil recovery (MEOR) and in the bioremediation of water and soils contaminated by hydrocarbon spills and heavy metals (Amani et al., 2013; Darvishi et al., 2011; Wu et al., 2008). Among the better-known biosurfactants are the rhamnolipids (RLs), mainly produced by the bacterium $P$. aeruginosa. 
Strains of $P$. aeruginosa can metabolize hexadecane and other polycyclic aromatic hydrocarbons to use them as a carbon source for growth, for synthesis of rhamnolipids (Beal and Betts, 2000; Müller et al., 2012; Nie et al., 2010) and to eliminate heavy metals from wastewater (El Zeftawy and Mulligan, 2011).

Rhamnolipids (the class glycolipids) from this species are known to function as antibacterial, antiviral, antiparasitic, sporicidal and antifungal agents (Abdel-Mawgoud et al., 2010; Bharali et al., 2013; Wang et al., 2005)alphaL-rhamnopyranosyl-alpha-L-rhamnopyranosyl-beta-hydroxydecanoate (Rha-Rha-C(10. Another compound related to biosurfactants is pyocyanin, which is a blue, secondary metabolite with the ability to oxidize and reduce other molecules (Hassan et al., 1980). Biosurfactants and pyocyanin exhibited a peculiar correlation, as the culture supernatants containing both components emulsified hydrocarbons in a higher amount than that of the biosurfactant alone.

Enhancement in emulsification also occurred by mixing pyocyanin from PPGAS medium and biosurfactant (Das and Ma, 2013). P. aeruginosa is a free-living bacterium that has been isolated from soils, contaminated water, plant rhizospheres, animal skin, leachates, and human environments, including hospitals (Soberón-Chávez, 2001). Resistance of many $P$. aeruginosa strains to antibiotics, antiseptics, chemical disinfectants, heavy metals and metalloids suggest that the species is generally robust in nature and may be applied for human uses in certain cases. The overall objective was to investigate biosurfactant, pyocyanin production, and tolerance to heavy metals and antimicrobial activity capacity than biosurfactants produced from $P$. aeruginosa strains from corn rhizosphere and compost in Mexico.

\section{MATERIALS AND METHODS}

See Annex.

\section{RESULTS AND DISCUSSION RESULTS}

Selection and identification of biosurfactantproducing bacteria.

A total of seven bacterial strains were characterized genetically and identified as the genus Pseudomonas. Four isolates were found in Zea mays rhizosphere (PAM7, PAM8, PAM9 and PAM 10) and the rest were isolated from compost (PAB11, PAB12 and PAB13). The strains showed 99\% identity to $P$. aeruginosa PAO1 (reference strain); however, PAM79 and PAM810 isolates are genetically related to strains of Pseudomonas $s p$ (Fig 1). All strains exhibited the ability to produce biosurfactants, which was confirmed by beta hemolysis in blood agar plates and dark halos in CTAB-Methylene blue agar. 


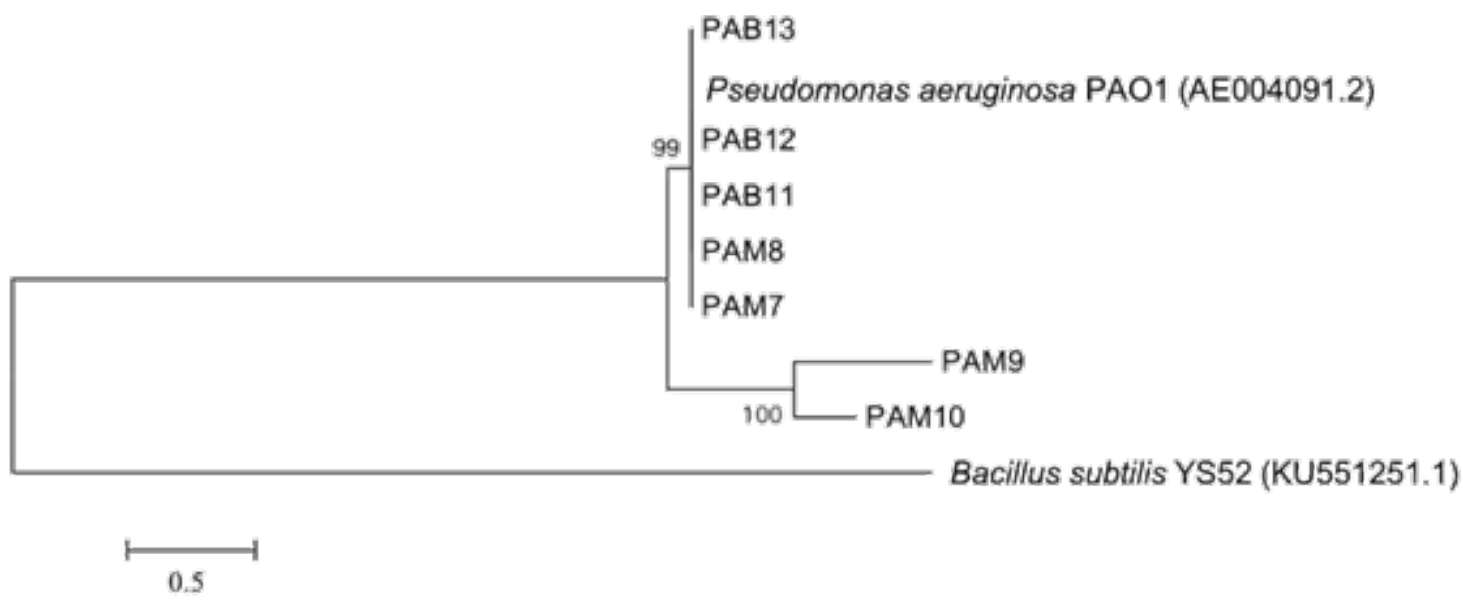

Figure 1. Phylogenic analysis by neighbor-joining method on $16 \mathrm{~S}$ rDNA gene sequences. Scale bar $=0.5$ substitutions per nucleotide position. Bacillus subilis YS52 (HQ202539) was used as an outgroup sequence.

Source: Authors

The surface activity of biosurfactants present foaming activity in PPGAS broth, drop collapse in the cultures was positive for the tests of test and oil displacement test (Fig. 2).
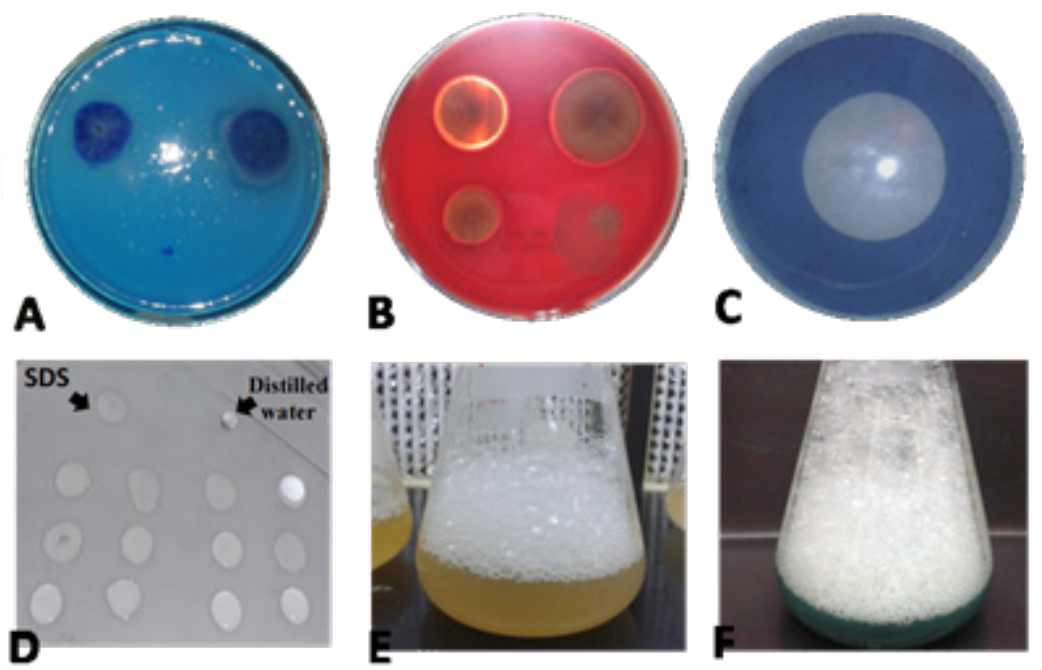

Figure 2, Evaluation of the production of biosurfactants. A) Blue halos formation in CTAB-Methylene blue agar, B) Hemolysis in blood agar. C) oil displacement assay. D) drop collapse test. E-F) Foaming activity in PPGAS broth.

Source: Authors

Emulsifying properties and cellular hydrophobicity associated with biosurfactants production

The biosurfactants produced can emulsify petroleum, diesel, toluene, xylene, cyclohexane and oils (mineral and vegetable) in different degrees, as shown on Table 1. The xylene hydrocarbon was mostly emulsified by the strains (average $=58 \%$ ), while mineral oil did not exceed the $32 \%$ of average emulsification. $P$. aeruginosa strains with highest $\mathrm{IE}_{24}$ values were PAM8, PAM9, PAB11 and PAB13. 
The strain PAM8 has an average $\mathrm{IE}_{24}$ of $64 \%$ and PAM9 emulsifies cyclohexane up to $70 \%$ in vegetable oil. PAB11 emulsifies petroleum to $79 \%$ and PAB13 emulsifies xylene to $67 \%$. The Zea mays rhizosphere strains showed better emulsification in diesel compared to the compost strains, and did not present significant differences in the other substrates. The strongly hydrophobic (\% Cellular Hydrophobicity or BATH) $P$. aeruginosa strains were PAM8 and PAM9 with $38 \%$ and $30 \%$ of BATH values, respectively (Table 1 ).

Table 1. Percent Index of emulsification $\left(\mathrm{IE}_{24}\right)$ and cellular hydrophobicity

by biosurfactants of $P$. aeruginosa.

Table 1. Percent Index of emulsification (IE 24) and cellular hydrophobicity by biosurfactants of Pseudomonas aeruginosa.

\begin{tabular}{cccccccccc}
\hline \multicolumn{10}{c}{ Emulsification Index (IE24)\% } \\
\hline Sample & P. aeruginosa & Diesel & Toluene & Xylene & Cyclohexane & Mineral Oil & Vegetable oil & Petroleum & \% Cellular Hydrophobicity \\
\hline \multirow{3}{*}{ Maize } & PAM7 & 28 & 66 & 57 & 54 & 24 & 45 & 20 & 22 \\
rhizosphere & PAM8 & 60 & 24 & 61 & 64 & 33 & 52 & 26 & 38 \\
& PAM9 & 56 & 66 & 67 & 65 & 23 & 70 & 26 & 30 \\
& PAM10 & 40 & 19 & 42 & 54 & 17 & 55 & 56 & 18 \\
\hline \multirow{3}{*}{ Compost } & PAB11 & 27 & 63 & 47 & 54 & 21 & 50 & 79 & 22 \\
& PAB12 & 12 & 54 & 63 & 44 & 60 & 57 & 22 & 18 \\
& PAB13 & 25 & 24 & 67 & 48 & 44 & 45 & 44 & 26 \\
\hline Control & PAO-1 & 57 & 54 & 65 & 45 & 42 & 54 & 73 & 32 \\
\hline & Pvalue & $0.04 *$ & 0.86 & 0.65 & 0.25 & 0.21 & 0.48 & 0.42 & 0.06 \\
\hline
\end{tabular}

*Statistically different accorded to unpaired Student's t-test ( $p \leq 0.05)$

Source: Authors

Quantification and physicochemical characterization of biosurfactants.

The $P$. aeruginosa strains with the highest bio-

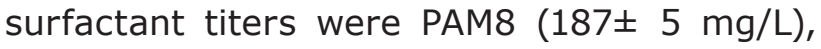
from Zea mays rhizosphere, and PAB13 (162 \pm 7 $\mathrm{mg} / \mathrm{L}$ ), from compost (Fig.3). The strain PAB12 showed poor performance, with $125 \pm 4 \mathrm{mg} / \mathrm{L}$ of biosurfactant. All biosurfactants obtained from the isolated Pseudomonas strains were negatively charged and retained their capacity to disperse and emulsify oil after treatment at $\geq 100{ }^{\circ} \mathrm{C}$, salinity at $10 \%$ and $\geq \mathrm{pH} 10$ (Fig. 3). Significant differences were observed between compost and Zea mays rhizosphere strains in terms of amount of biosurfactant produced but not in their physicochemical properties. 


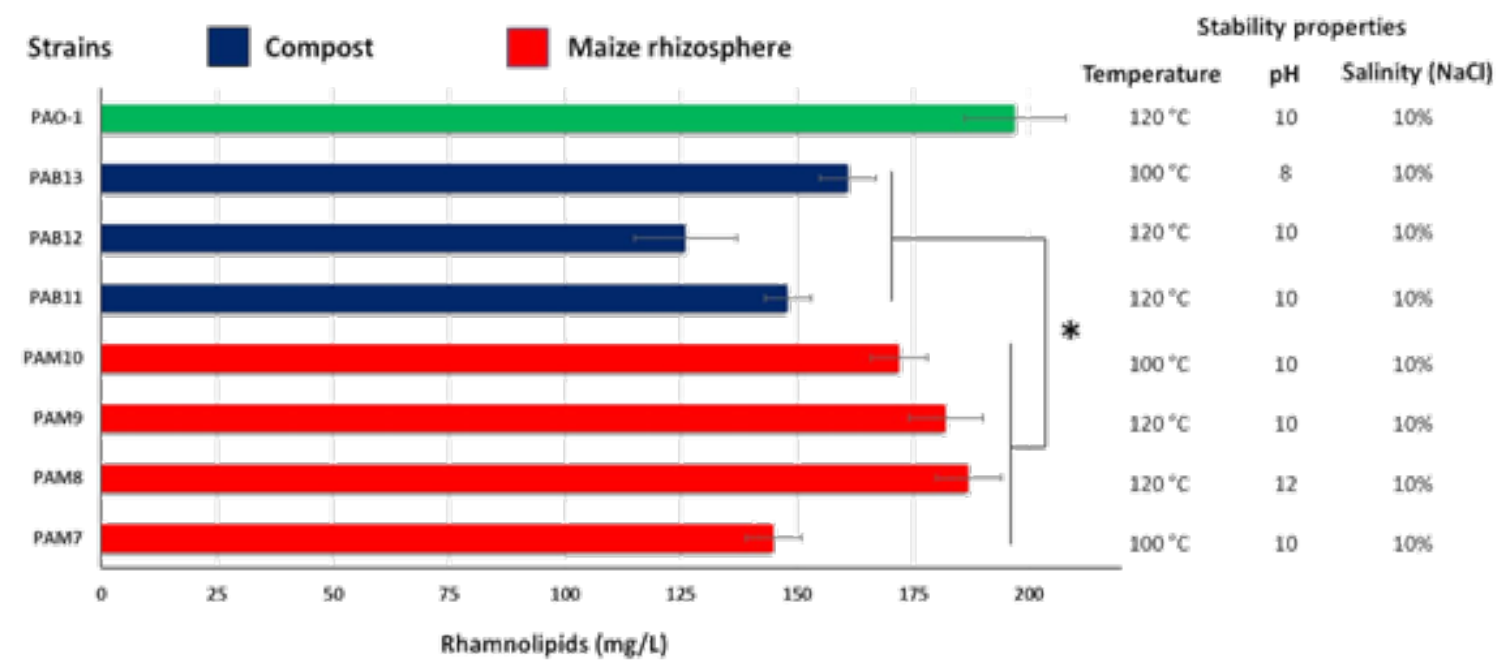

Figure 3. Comparison of production and physicochemical properties of rhamnolipids. "Statistically different between compost and rhizosphere strains accorded to unpaired Student's t-test ( $\mathrm{p} \leq 0.05)$

Source: Authors

Surface activity of biosurfactants in presence of pyocyanin pigment.

The production of pigments was observed at the same time as formation of abundant foam in PPGAS culture so, due to its blue coloration, pyocyanin was quantified (Fig. 4). The highest production of pyocyanin was observed in Zea mays rhizosphere strains: PAM8 $\left(11.9 \pm 2.3 \mu \mathrm{L} \mathrm{mL}^{-1}\right)$, PAM9 $(7.8 \pm 1.3$ $\left.\mu \mathrm{L} \mathrm{mL}{ }^{-1}\right)$ and PAM10 $\left(7.8 \pm 1.0 \mu \mathrm{LL}^{-1}\right)$.
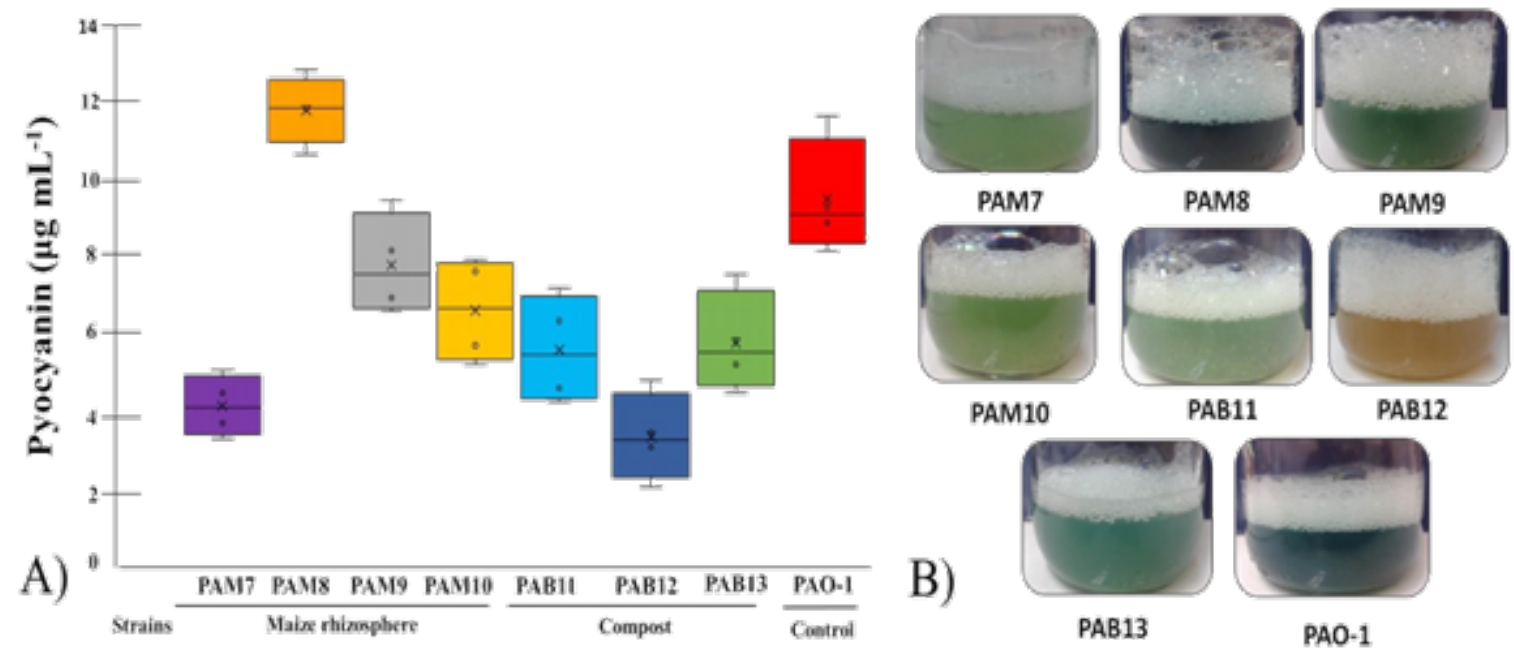

PAM8

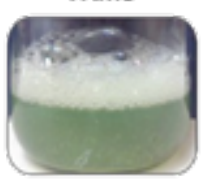

PAB11
PAM9

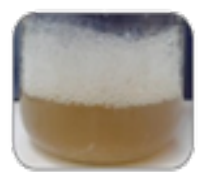

PAB12

B)

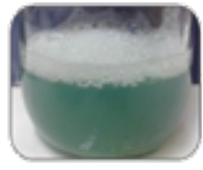

PAB13

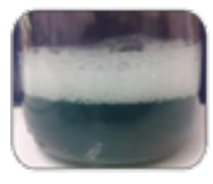

PAO-1

Figure 4 Comparison of pyocyanin pigment between compost and rhizosphere strains, A) Quantification by colorimetric method. B) Intensity of pigment in PPGAS broth.

Source: Authors 
Antibacterial activity of biosurfactants.

The produced rhamnolipids have antimicrobial activity against two Grampositive and two Gramnegative bacteria evaluated (Table 2). Maize rhizosphere strains inhibit the bacterium Bacillus subtilis better than compost strains, and no significant differences in their antibacterial effect were observed for other bacteria. $P$. aeruginosa PAM8 showed the strongest activity against $B$. subtilis, $S$. aureus, S. paucimobilis and $K$. pneumoniae with inhibition halos of $26 \pm 6 \mathrm{~mm}, 22 \pm 4 \mathrm{~mm}, 32 \pm 5$ $\mathrm{mm}$ and $24 \pm 3 \mathrm{~mm}$, respectively.

Table 2. Comparison of antibacterial activity of biosurfactants produced by Pseudomonas aeruginosa.

\begin{tabular}{|c|c|c|c|c|c|c|c|c|}
\hline & \multicolumn{8}{|c|}{ Inhibition zone diameter $(\mathrm{mm})$} \\
\hline & $\begin{array}{c}P . \\
\text { aeruginosa }\end{array}$ & $\begin{array}{c}\text { B. } \\
\text { subtilis }\end{array}$ & $\begin{array}{c}\text { S. } \\
\text { aureus }\end{array}$ & $\begin{array}{l}\text { S. } \\
\text { paucimobilis }\end{array}$ & $\begin{array}{c}E . \\
\text { cloacae }\end{array}$ & $\begin{array}{c}\text { P. } \\
\text { vulgaris }\end{array}$ & $\begin{array}{c}\text { K. } \\
\text { pneumoniae }\end{array}$ & $\begin{array}{c}\text { E. } \\
\text { coli }\end{array}$ \\
\hline \multirow{4}{*}{$\begin{array}{l}\text { Maize } \\
\text { rhizosphere }\end{array}$} & PAM7 & 22 & 20 & 21 & ND & ND & 13 & ND \\
\hline & PAM8 & 26 & 22 & 32 & ND & ND & 24 & ND \\
\hline & PAM9 & 23 & 13 & 22 & ND & ND & 14 & ND \\
\hline & PAM10 & 23 & 17 & 26 & ND & ND & 18 & ND \\
\hline \multirow{3}{*}{ Compost } & PAB11 & 11 & 12 & 31 & ND & ND & 17 & ND \\
\hline & PAB12 & 13 & 19 & 12 & ND & ND & 13 & ND \\
\hline & PAB13 & 21 & 17 & 16 & ND & ND & 19 & ND \\
\hline \multirow[t]{2}{*}{ Control } & PAO-1 & 26 & 21 & 30 & ND & ND & 23 & ND \\
\hline & $p$ value & $0.03 *$ & 0.94 & 0.82 & - & - & 0.84 & - \\
\hline
\end{tabular}

Source: Authors

Heavy-metal resistance profile of $P$. aeruginosa strains.

The petroleum and its derivatives contain traces of heavy metals and metalloids that give rise to the formation of organometallic compounds; therefore, we evaluated the heavy-metal resistance profile of biosurfactantproducing Pseudomonas. All the strains have similar MIC to heavy metals and metalloids in the following order: $\mathrm{As}^{5+}(>20 \mathrm{mM}), \mathrm{As}^{3+}(10$ $\mathrm{mM}), \mathrm{Zn}^{2+}(10 \mathrm{mM}), \mathrm{Pb}^{2+}(6 \mathrm{mM}), \mathrm{Fe}^{3+}(4 \mathrm{mM})$, $\mathrm{Cd}^{2+}(4 \mathrm{mM}), \mathrm{Cu}^{2+}(2 \mathrm{mM})$ and $\mathrm{Cr}^{6+}(2 \mathrm{mM})$. The colonies were hyper mucoid when grown in high concentrations of metals especially in $\mathrm{Pb}$, $\mathrm{Fe}$ and $\mathrm{Cu}$.

\section{DISCUSSION}

The bacterium $P$. aeruginosa is known for its ability to produce several bioactive compounds. In this study, report is made on seven strains isolated from the rhizosphere corn or compost; all isolates produced biosurfactants with emulsification indexes on the different hydrophobic substrates as shown on Table 1. Highlighted in the work by Pirôllo et al. (2008), a P. aeruginosa LBI strain was isolated from places that were contaminated by hydrocarbons. The biosurfactant produced maintained the physicochemical properties after treatment at $120{ }^{\circ} \mathrm{C}, 10 \%$ salinity and only PAM8 biosurfactant is active under alkaline conditions ( $\mathrm{pH} 12$ ). 
Strains synthetized both mono-rhamnolipids and di-rhamnolipids, except PAB12 that only produces mono-rhamnolipid, probably lacks some gene responsible for incorporating rhamnose during the biosynthetic pathway. Our results of $\mathrm{IE}_{24}$ agree with the results obtained by Janek et al., (2013), where it was reported that the rhamnolipid produced by a strain of Pseudomonas BD2 isolated in the Arctic, is capable of reducing the surface tension from 71 to $31 \mathrm{mN} / \mathrm{m}$ and emulsifies $70 \%$ olive oil, meanwhile for n-hexane, xylene, hexadecane and petroleum ether it emulsifies in a range from 51 to $65 \%$.

It was observed that strains that synthesize more pigment also produce more biosurfactant and are better emulsifiers. Das and $\mathrm{Ma}$ (2013) report that the pyocyanin pigment enhances the biosurfactant-mediated hydrocarbon emulsification in clinical and environmental strains of $P$. aeruginosa. In the same way, the hydrocarbonoclastic activity (involved in the mineralization of hydrocarbon pollutants) is positively correlated with the pyocyanin production by $P$. aeruginosa strains isolated from gas stations, activated sludge and wastewater (Viana et al., 2018). Since the strains isolated in the present study are biosurfactant producers, they could potentially be used for Microbial Enhanced Oil Recovery (MEOR) in contaminated environments, in oil wells (Brown, 2010) or in agricultural soils (Sachdev and Cameotra, 2013). The production and concentrations the biosurfactants vary depending on the culture conditions and nutrients, especially the carbon source, as reported by Vanavil et al. (2013) It was reported that the concentration of rhamnolipids obtained when growing the strain in glucose was $88 \mathrm{mg} / \mathrm{L}$, and 15-fold higher when they added $\mathrm{Mg}^{2+}$ and $\mathrm{Fe}^{2+}$ to the media. In the case of this study, it is still needed to find conditions for the improvement of the biosurfactant production.
We propose PAM8, PAM9 and PAM13 strains as candidates for use in bioremediation of marine environments and other systems by biosurfactants that are stable in hypersaline and alkaline conditions. The strains in this study are similar to those that the microbial consortium reported by Darvishi et al. (2011). That consortium produces a biosurfactant capable of resisting temperatures of over $70^{\circ} \mathrm{C}$, salt concentrations higher than $15 \%$, and a range of $\mathrm{pH}$ from 4 to 10 . It also breaks down hydrocarbons, a fact that points it as a good candidate for the remediation of contaminated sites with these compounds.

The strains PAM8 and PAM9 are capable to emulsify different hydrocarbons and have highest cell hydrophobicity, these are good features for the bioremediation of sites contaminated with oil. Kaczorek and Olszanowski (2010) evaluated the binding of hydrocarbons by Pseudomonas $s p$. when growing in different carbon sources. They observed that $P$. fluorescens PI growing in glucose had $8 \%$ hydrophobicity but when grown in ethylbenzene, its hydrophobicity increased by $30 \%$ similar to the hydrophobicity showed by the strains $P$. aeruginosa PAM8 (28\%) and $P$. aeruginosa PAM9 (20\%). PAB12 is the smallest emulsifier probably because it only produces mono-rhamnolipid in small quantities (Fig 3), so the critical micellar concentration is not easily achieved.

The crude extracts of strain PAM8 showed high activity against $B$. subtilis, S. aureus, S. paucimobilis and $K$. pneumoniae. These results are consistent with Bharali et al. (2013) where the antibacterial activity of the $P$. aeruginosa OBP1 rhamnolipids on $S$. aureus and $K$. pneumoniae was shown. The rhamnolipids produced by $P$. putida $21 \mathrm{BN}$ against $B$. subtillus (Tuleva et al., 2002). Another study showed the effect of the biosurfactant produced by $P$. koreensis M9b on Grampositive bacteria (Toribio et al., 
2011). The antibacterial producers included in the CLSI (Clinical and Laboratory Standards Institute) to date are biosurfactants belonging to the class glycolipids and cyclic lipopeptides; for this reason, the biosurfactants produced by our isolates represent good candidates as antibacterial products.

The colonies showed fluorescence and were hyper-mucoid in presence of $\mathrm{Pb}, \mathrm{Zn}$ and Fe. This was probably in response to the stress they underwent, since the exopolysaccharides have anionic functional groups as phosphates, sulfates, and carboxilic acids that bind to metals, sequestering them and avoiding the interactions of the metal inside the cell. Fluorescence was caused by the production of siderophores that could be related to the presence of specific metals in the soils that our isolates came from. Siderophores as the pioverdine and piochelin are able to bind $\mathrm{Fe}, \mathrm{Cd}$, $\mathrm{Cu}$ and $\mathrm{Zn}$, reducing their toxicity for bacteria (Dao et al., 1999; Dimkpa et al., 2009).

These data agree with Raja et al. (2006), who reported on a strain of $P$. aeruginosa FC1 being capable of growing in $800 \mathrm{ppm}$ of $\mathrm{Pb}, 700 \mathrm{ppm}$ of $\mathrm{Ni}, 500 \mathrm{ppm}$ of $\mathrm{Cd}$ and $400 \mathrm{ppm}$ of $\mathrm{Cr}$. On the other hand, studies conducted by Hassan et al. (2008) showed bacterial resistance to heavy metals in contaminated soils in Egypt. However, $89 \%$ of the isolates were inhibited by $3.5 \mathrm{mM}$ of the metal, which represents a lower concentration than our isolates could resist. Bodour et al. (2003) This shows the production of associated biosurfactants with resistance to heavy metals, which is similar to the yield of this study.

\section{CONCLUSIONS}

Seven endemic strains of $P$. aeruginosa were successfully isolated from the rhizosphere from pure breed Zea mays and compost. The strains were able to produce rhamnolipid and has antimicrobial activity against Grampositive and Gramnegative bacteria. Moreover, they showed resistance to heavy metals. Strains PAM8 and PAM9, are the best candidates to use them for bioremediation and other biotechnological applications.

\section{AUTHOR'S CONTRIBUTION}

First author: Methodology, research, data analysis, conceptualization, writing, original draft. Second author: Research, conceptualization, data analysis, writing, review and editing. Third author: Logistics, review and edition. Fourth author: data analysis, review and editing. Fifth author: Resource acquisition, project manager, supervision, conceptualization, writing, review and editing.

\section{ACKNOWLEDGMENTS}

We thank J Ramos from School of Plant Sciences, University of Arizona for assistance with molecular sequencing of the bacterial isolates, and J Guevara Luna and JD Chávez Gonzalez for technical assistance.

\section{LITERATURE CITED}

Abdel-Mawgoud, A., Lépine, F. and Déziel, E., (2010). Rhamnolipids: diversity of structures, microbial origins and roles. Applied Microbiology and Biotechnology, 86(5), pp.1323-1336. doi: $10.1007 / \mathrm{s} 00253-010-2498-2$.

Amani, H., Müller, M., Syldatk, C. and Hausmann, R., (2013). Production of Microbial Rhamnolipid by Pseudomonas Aeruginosa MM1011 for Ex Situ Enhanced Oil Recovery. Applied Biochemistry and Biotechnology, 170(5), pp.1080-1093. doi: 10.1007/s12010-013-0249-4.

Beal, R. and Betts, W., (2000). Role of rhamnolipid biosurfactants in the uptake and mineralization of hexadecane in Pseudomonas aeruginosa. Journal of Applied Microbiology, 89(1), pp.158168. doi: 10.1046/j.1365-2672.2000.01104.x.

Bharali, P., Saikia, J., Ray, A. and Konwar, B., (2013). Rhamnolipid (RL) from Pseudomonas aeruginosa OBP1: A novel chemotaxis and antibacterial agent. Colloids and Surfaces B: Biointerfaces, 103, pp.502-509. doi: 10.1016/j.colsurfb.2012.10.064. 
Bodour, A., Drees, K. and Maier, R., (2003). Distribution of Biosurfactant-Producing Bacteria in Undisturbed and Contaminated Arid Southwestern Soils. Applied and Environmental Microbiology, 69(6), pp.3280-3287. doi: 10.1128/ AEM.69.6.3280-3287.2003

Boles, B., Thoendel, M. and Singh, P., (2005). Rhamnolipids mediate detachment of Pseudomonas aeruginosa from biofilms. Molecular Microbiology, 57(5), pp.1210-1223. doi: 10.1111/j.1365-2958.2005.04743.x.

Brown, L., (2010). Microbial enhanced oil recovery (MEOR). Current Opinion in Microbiology, 13(3), pp.316-320. doi: 10.1016/j.mib.2010.01.011

Dao, K., Hamer, K., Clark, C. and Harshman, L., (1999). Pyoverdine production by Pseudomonas aeruginosa exposed to metals or an oxidative stress agent. Ecological Applications, 9(2), pp.441-448. doi 10.1890/10510761(1999)009[0441: PPBPAE]2.0.CO;2",

Darvishi, P., Ayatollahi, S., Mowla, D. and Niazi, A., (2011). Biosurfactant production under extreme environmental conditions by an efficient microbial consortium, ERCPPI-2. Colloids and Surfaces B: Biointerfaces, 84(2), pp.292-300. doi: 10.1016/j.colsurfb.2011.01.011.

Das, P. and Ma, L., 2013. Pyocyanin pigment assisting biosurfactant-mediated hydrocarbon emulsification. International Biodeterioration \& Biodegradation, 85, pp.278-283. doi 10.1016/j. ibiod.2013.07.013

Dimkpa, C., Merten, D., Svatoš, A., Büchel, G. and Kothe, E., (2009). Siderophores mediate reduced and increased uptake of cadmium byStreptomyces tendaeF4 and sunflower (Helianthus annuus), respectively. Journal of Applied Microbiology, 107(5), pp.1687-1696. doi: 10.1111/j.1365-2672.2009.04355.x.

El Zeftawy, M. and Mulligan, C., (2011). Use of rhamnolipid to remove heavy metals from wastewater by micellar-enhanced ultrafiltration (MEUF). Separation and Purification Technology, 77(1), pp.120-127. doi:10.1016/j.seppur.2010.11.030

Hassan, H. and Fridovich, I., (1980). Mechanism of the antibiotic action pyocyanine. Journal of Bacteriology, 141(1), pp.156-163. doi: 10.1128/ JB.141.1.156-163.1980

Hassan, S., Abskharon, R., Gad El-Rab, S. and Shoreit, A., (2008). Isolation, characterization of heavy metal resistant strain of Pseudomonas aeruginosa isolated from polluted sites in Assiut city, Egypt. Journal of Basic Microbiology, 48(3), pp.168-176. doi: 10.1002/jobm.200700338.

Janek, T., Łukaszewicz, M., \& Krasowska, A. (2013). Identification and characterization of biosurfactants produced by the Arctic bacterium Pseudomonas putida BD2. Colloids and Surfaces B: Biointerfaces, $110,379-386$. doi: 10.1016/j.colsurfb.2013.05.008.

Kaczorek, E., \& Olszanowski, A. (2010). Uptake of Hydrocarbon by Pseudomonas fluorescens (P1) and Pseudomonas putida (K1) Strains in the Presence of Surfactants: A Cell Surface Modification. Water, Air, \& Soil Pollution, 214(1-4), 451459. Doi:10.1007/s11270-010-0436-7

Maier, R. M., \& Soberón-Chávez, G. (2000). Pseudomonas aeruginosa rhamnolipids: biosynthesis and potential applications. Applied Microbiology and Biotechnology, 54(5), 625-633. Doi:10.1007/ s002530000443

Müller, M. M., Kügler, J. H., Henkel, M., Gerlitzki, M., Hörmann, B., Pöhnlein, M., Syldatk, C., \& Hausmann, R. (2012). Rhamnolipids-Next generation surfactants? Journal of Biotechnology, 162(4), 366-380. doi: 10.1016/j.jbiotec.2012.05.022

Nie, M., Yin, X., Ren, C., Wang, Y., Xu, F., \& Shen, Q. (2010). Novel rhamnolipid biosurfactants produced by a polycyclic aromatic hydrocarbon-degrading bacterium Pseudomonas aeruginosa strain NY3. Biotechnology Advances, 28(5), 635-643. doi: 10.1016/j.biotechadv.2010.05.013

Pacwa-Płociniczak, M., Płaza, G. A., Piotrowska-Seget, Z., \& Cameotra, S. S. (2011). Environmental Applications of Biosurfactants: Recent Advances. International Journal of Molecular Sciences, 12(1), 633-654. doi: 10.3390/ijms12010633.

Pirôllo, M. P. S., Mariano, A. P., Lovaglio, R. B., Costa, S. G. V. A. O., Walter, V., Hausmann, R., \& Contiero, J. (2008). Biosurfactant synthesis by Pseudomonas aeruginosa LBI isolated from a hydrocarbon-contaminated site. Journal of Applied Microbiology, 105(5), 1484-1490. doi: 10.1111/j.1365-2672.2008.03893.x.

Raja, C. E., Anbazhagan, K., \& Selvam, G. S. (2006). Isolation and Characterization of a Metal-resistant Pseudomonas Aeruginosa Strain. World Journal of Microbiology and Biotechnology, 22(6), 577-585. Doi: 10.1007/s11274-0059074-4 
Sachdev, D. P., \& Cameotra, S. S. (2013). Biosurfactants in agriculture. Applied Microbiology and Biotechnology, 97(3), 1005-1016. doi: 10.1007/ s00253-012-4641-8

Satpute, S. K., Banpurkar, A. G., Dhakephalkar, P. K., Banat, I. M., \& Chopade, B. A. (2010). Methods for investigating biosurfactants and bioemulsifiers: a review. Critical Reviews in Biotechnology, 30(2), 127-144. doi: 10.3109/07388550903427280.

Soberón-Chávez, G. (2001). Pseudomonas aeruginosa. In: Microbios en línea, capítulo 3. Martínez Romero E. and Martínez Romero J. (eds). DGSCA, UNAM, http:// www.microbiologia.org.mx/ microbiosenlinea/.

Toribio, J., Escalante, A. E., Caballero-Mellado, J., González-González, A., Zavala, S., Souza, V., \& Soberón-Chávez, G. (2011). Characterization of a novel biosurfactant producing Pseudomonas koreensis lineage that is endemic to Cuatro Ciénegas Basin. Systematic and Applied Microbiology, 34(7), 531-535. doi: 10.1016/j.syapm.2011.01.007.

Toribio-Jiménez, J., Rodríguez-Barrera, MA., Valdez, M., Barrera, A., Segura, D., Wilson-Corral, V and Romero Y. (2014). Production of biosurfactants by bacteria isolated from a mine tailing zone in Southern Mexico and their resistance to heavy metals. J. bacteriol research, 6(2), 13-16. DOI: $10.5897 / j b r 2014.0128$
Tuleva, B. K., Ivanov, G. R., \& Christova, N. E. (2002). Biosurfactant Production By a New Pseudomonas Putida Strain. Zeitschrift Für Naturforschung C, 57(3-4), 356-360. doi: 10.1515/znc-2002-3-426.

Vanavil, B. (2013). Biosurfactant Production from Novel Air Isolate NITT6L: Screening, Characterization and Optimization of Media. Journal of Microbiology and Biotechnology, 23(9), 1229-1243. DOI: $10.4014 / \mathrm{jmb} .1212 .12031$

Viana, A. A. G., Oliveira, B. T. M. de, Cavalcanti, T. G., Sousa, K. A. de, Mendonça, E. A. de M., Amaral, I. P. G. do, \& Vasconcelos, U. (2018). Correlation between pyocyanin production and hydrocarbonoclastic activity in nine strains of Pseudomonas aeruginosa. International Journal of Advanced Engineering Research and Science, 5(7), 212-223. DOI: 10.22161/ijaers.5.7.28

Wang, X., Gong, L., Liang, S., Han, X., Zhu, C., \& Li, Y. (2005). Algicidal activity of rhamnolipid biosurfactants produced by Pseudomonas aeruginosa. Harmful Algae, 4(2), 433-443. DOI: 10.1016/j. hal.2004.06.001

Wu, J.-Y., Yeh, K.-L., Lu, W.-B., Lin, C.-L., \& Chang, J.-S. (2008). Rhamnolipid production with indigenous Pseudomonas aeruginosa EM1 isolated from oil-contaminated site. Bioresource Technology, 99(5), 1157-1164. doi: 10.1016/j.biortech.2007.02.026.
Conflicto de Intereses Los autores declaran no tener ningún conflicto de intereses 